\title{
INTERFERENSI BAHASA MELAYU MALAYSIA TERHADAP BAHASA INDONESIA PADA MASYARAKAT TKI KECAMATAN SIKUR
}

\section{(THE INTERFERENCE OF MALAYAN LANGUANGE TO INDONESIAN LANGUAGE OF THE MIGRANT WORKERS POPULATIONS IN SUB-DISTRIC OF SIKUR)}

\author{
Muh. Jaelani Al-Pansori \\ STKIP Hamzanwadi Selong \\ Jalan TGKH Zainuddin Abdul Madjid No.132 Pancor 83612, Selong, NTB, Indonesia \\ Pos-el: jaelani_alpan@yahoo.com
}

Diterima: 3 Oktober 2014; Direvisi: 20 November 2014; Disetujui: 3 Desember 2014

\begin{abstract}
It is a common phenomenon that many rural populations work in Malaysia well known as Indonesian Labors (TKI). Even, some of them have been working for 5 years without passport. Their long period serving as Malaysian TKI affects to the ungrammatical and interference usage of Indonesian language. This study focuses on the causes and interferences form of Malayan language towards the TKI's Indonesian language performance in Sub-district of Sikur. This is descriptive and qualitative study. The data is collected by using recording and interview technique. Then, the recording data is transcribed into written form and is analyzed by using interactive analysis with the following steps: data collection, data reduction, data display, and conclusion. Based on the data analysis, it is concluded that the interferences occurred among the Malaysian TKI populations are caused by interaction, habitual use of Malayan language for communication and their long period serving as TKI. In addition, forms of language interferences of the Malaysian TKI are phonological interference which occurs through shift of vowel phoneme, shift of consonant phoneme, and articulation of vowel and consonant phoneme. Beside that, morphological interference also occurs through prefix di-, clitics -nya, preposition di, full reduplication and partial reduplication. Finally, syntactic interference occurs in term of function, category and role.
\end{abstract}

Keywords: interference, Malayan language, Indonesian language

\begin{abstract}
Abstrak
Fenomena yang sering kita lihat bahwa masyarakat pedesaan mayoritas menjadi Tenaga Kerja Indonesia (TKI) di Malaysia. Bahkan ada yang bekerja sampai 5 tahun tanpa paspor. Akibat lamanya menjadi TKI di Malaysia, penggunaan bahasa Indonesia menjadi tidak gramatikal yang menyebabkan terjadinya interferensi bahasa. Penelitian ini memfokuskan kajian pada penyebab dan bentuk interferensi bahasa Melayu Malaysia terhadap bahasa Indonesia pada masyarakat TKI di kecamatan Sikur. Jenis penelitian ini adalah deskriptif kualitatif. Teknik pengumpulan data dilakukan dengan teknik sadap dan wawancara. Data yang direkam kemudian ditranskripkan dalam bentuk tulisan dan dianalisis dengan analisis interaktif, yakni data collection, data reduction, data display, dan conclution. Berdasarkan hasil analisis data, dapat disimpulkan bahwa penyebab terjadinya interferensi pada TKI Malaysia yaitu, karena pergaulan para TKI dengan orang Melayu, kebiasaan menggunakan bahasa Malaysia ketika berkomunikasi di Malaysia, dan lamanya menjadi TKI di Malaysia. Bentuk interferensi bahasa Malaysia terhadap bahasa Indonesia yaitu, interferensi fonologi, morfologi, dan sintaksis. Interferensi fonologi terjadi dalam beberapa bentuk, yakni perubahan fonem vokal, perubahan fonem konsonan, dan pelesapan fonem vokal dan konsonan. Interferensi morfologi hanya terdapat pada kata depan $\{\mathrm{ka}\}$. Selain itu, Interferensi sintaksis pada TKI Malaysia terdapat pada kategori dan peran.
\end{abstract}

Kata kunci: interferensi, bahasa Melayu, bahasa Indonesia 


\section{Pendahuluan}

Bahasa merupakan alat komunikasi yang tidak bisa terlepas dari kehidupan sosial masyarakat. Dalam kehidupan sosial, kita mengetahui adanya masyarakat yang terbuka. Masyarakat tersebut dapat menerima kedatangan dari anggota masyarakat lain. Bahasa dari masyarakat yang menerima kedatangan akan saling mempengaruhi dengan bahasa dari masyarakat yang datang. Dari peristiwa penerimaan tersebut, maka akan terjadi apa yang disebut kontak bahasa. Hal yang paling menonjol dari adanya kontak bahasa antara masyarakat yang satu dengan masyarakat yang lain adalah terjadinya bilingualisme dan multilingualisme.

Multilingualisme yang terjadi dalam kontak bahasa, menciptakan adanya integrasi dan interferensi. Kedua hal tersebut memiliki gejala yang sama, yaitu adanya unsur bahasa lain dalam bahasa yang digunakan, hanya saja konsep masalahnya yang berbeda. Integrasi dikatakan sebagai gejala bahasa karena terjadi pada setiap anggota masyarakat dan peristiwanya tidak lagi dianggap sebagai penyimpangan karena sudah menyatu dan diterima oleh masyarakat. Sementara itu, interferensi dikatakan sebagai gejala tutur (speech, parole) karena hanya terjadi pada dwibahasawan, sehingga peristiwanya dianggap sebagai penyimpangan.

"Istilah interferensi pertama kali digunakan oleh Weinreich (1953) untuk menyebut adanya perubahan sistem suatu bahasa sehubungan dengan adanya persentuhan bahasa tersebut dengan unsurunsur bahasa lain yang dilakukan oleh penutur yang bilingual" (Chaer dan Agustina, 2010:120). Pendapat tersebut memberikan penjelasan bahwa penutur bilingual adalah orang yang mampu atau bisa menggunakan dua bahasa. Bilingual dalam bahasa Indonesia disebut dwibahasawan.
Bloomfield (1995:45) menegaskan bahwa "bilingualisme adalah kemampuan seorang penutur untuk menggunakan dua bahasa dengan sama baiknya". Penjelasan tersebut memberikan pemahaman bahwa seseorang dikatakan bilingual apabila seseorang tersebut menguasai B1 dan B2 sama baiknya. Fenomena bilingualisme yang terjadi di Indonesia sangat beragam. Hal ini disebabkan adanya beragam etnis yang memiliki bahasa tersendiri.

Warga negara Indonesia dikatakan bilingual karena sebagian besar masyarakat Indonesia menguasai lebih dari satu bahasa. Dua bahasa yang dimaksud yakni, bahasa pertama (bahasa ibu) - disingkat (B1) - yang diperoleh pertama kali, dan bahasa kedua (bahasa yang diperoleh setelah bahasa ibu) yang disingkat (B2). B2 yang diperoleh bisa saja bahasa Indonesia atau bahasa asing. Fenomena pemerolehan B2 sering terjadi pada masyarakat pedesaan yang B1-nya adalah bahasa ibu, bisa saja mereka memperoleh B2 dengan bahasa asing. Kejadian itu disebabkan kurang mampunya orang tua untuk membiayai sekolah anaknya sehingga anak tersebut tidak mendapatkan pendidikan untuk memperoleh bahasa Indonesia sebagai B2-nya. Ia akhirnya lebih memilih untuk pergi merantau ke tanah seberang.

Masyarakat pedesaan dikenal sebagai salah satu penyumbang TKI terbesar yang berangkat ke Malaysia. Salah satu masyarakat pedesaaan yang dimaksud adalah masyarakat desa yang ada di kecamatan Sikur. Masyarakat di daerah tersebut sebagian besar memilih bekerja sebagai tenaga kerja ke luar negeri dibandingkan dengan bekerja di daerah sendiri. Pilihan mereka disebabkan karena upah yang didapatkan tidak dapat memenuhi kebutuhan hidup sehari-hari. Komitmen masyarakat Sikur sebagai TKI tidak tanggung-tanggung. Mereka bahkan ada yang bekerja di Malaysia sampai 5 tahun 
tanpa paspor (gelap). Akibat lamanya menjadi TKI di Malaysia, penggunaan bahasa Indonesia menjadi tidak gramatikal. Ketika mereka diajak berbahasa Indonesia, mereka cenderung lebih menggunakan bahasa Malaysia dibanding bahasa Indonesia yang merupakan bahasa negaranya sendiri. Hal ini dikarenakan bahasa yang diperoleh setelah bahasa ibu adalah bahasa asing atau bahasa Malaysia itu sendiri.

Bahasa Malaysia dengan bahasa Indonesia memang tidak jauh berbeda, karena kedua bahasa tersebut terbentuk dari bahasa Melayu. Namun, tidak semua kosakata bahasa Malaysia sama maknanya dengan bahasa Indonesia. Salah satunya kata "pusing" yang dalam bahasa Malaysia artinya "putar", sedangkan dalam bahasa Indonesia memiliki arti "sakit kepala". Kata tersebut akan menimbulkan makna yang berbeda, sehingga membuat orang yang mendengar akan salah pemahaman. Peristiwa seperti inilah yang disebut sebagai interferensi.

Interferensi bahasa yang dilakukan oleh para TKI yang baru pulang ke kampung halamannya sangat beragam. Baik itu interferensi dari segi fonologi, morfologi, atau pun sintaksis. Semua interferensi tersebut dilakukan dalam bentuk kalimat yang diucapkan dengan lisan dan dilakukan oleh penutur yang bilingual.

Mengingat pentingnya masalah tersebut, perlu dilakukan penelitian lebih intensif. Untuk itu, tujuan penelitian ini adalah untuk mendeskripsikan penyebab dan bentuk interferensi bahasa Melayu Malaysia terhadap bahasa Indonesia pada masyarakat TKI di Kecamatan Sikur.

\section{Kerangka Teori}

\subsection{Kedwibahsaan}

Bahasa merupakan susunan teratur yang berpola dan membentuk makna. Chaer dan Agustina (2010: 12) mengatakan bahwa "bahasa berwujud lambang bunyi yang lazim disebut bunyi ujar atau bunyi bahasa". Setiap lambang bahasa melambangkan makna dan konsep. Umpamanya lambang bahasa yang berbunyi [polpen] melambangkan konsep atau makna 'sejenis alat tulis bertinta'. Pengertian di atas memberikan pemahaman bahwa setiap satuan ujaran bahasa memiliki makna. Jika ada lambang bunyi yang tidak memiliki konsep atau makna, maka lambang tersebut tidak termasuk dalam sistem suatu bahasa.

Masyarakat Indonesia disebut masyarakat aneka bahasa, karena memiliki beragam bahasa. Ragam bahasa tersebut diantaranya adalah bahasa daerah. Indonesia terdiri dari beberapa pulau dan masingmasing pulau tersebut memiliki bahasa daerah yang berbeda, maka Indonesia dikatakan sebagai negara kaya akan bahasa. Tidak mustahil bagi sebagian besar penduduk Indonesia mampu menggunakan dua bahasa. Penggunaan dua bahasa disebut kedwibahasaan atau bilingualisme, sedangkan orang yang menggunakan dua bahasa disebut bilingual atau dwibahasawan.

Weinreich (dalam Aslinda dan Leni, 2010:23) mengatakan bahwa "kedwibahasaan adalah the practice of alternately using two languages (kebiasaan menggunakan dua bahasa atau lebih secara bergantian)". Pendapat yang hampir sama dikemukakan oleh Chaer dan Agustina (2010: 84) bahwa "bilingualisme yaitu berkenaan dengan penggunaan dua bahasa atau dua kode bahasa."

Sangat jelas dari beberapa pernyataan pakar di atas bahwa kedwibahasaan adalah penggunaan dua bahasa secara bergantian yang dilakukan oleh seorang penutur. Seseorang dapat menggunakan dua bahasa tentu harus menguasai dua bahasa, yakni B1 dan B2. Bisa jadi, B2 yang diperoleh adalah bahasa Indonesia atau bahasa asing. Kedwibahasaan ada akibat terjadinya kontak bahasa antara bahasa yang satu dengan bahasa yang lain yang dilakukan oleh 
masyarakat terbuka yang dapat menerima kedatangan masyarakat lain.

\subsection{Interferensi Bahasa}

Mengenal dua bahasa, apalagi mampu menggunakan dua bahasa, tidak akan menutup kemungkinan terjadinya interferensi. Kedwibahasaan dan interferensi sangat erat kaitannya. Hal ini dapat dilihat pada pemakaian bahasa dalam kehidupan sehari-hari. Situasi kebahasaan masyarakat tutur bahasa Indonesia sekurang-kurangnya ditandai dengan pemakaian dua bahasa, yaitu bahasa daerah sebagai B1, dan bahasa Indonesia sebagai B2. Situasi pemakaian seperti inilah yang dapat memunculkan percampuran antara B1 dan B2 (Dardjowidjojo 2003:246). Bahasa ibu yang dikuasai pertama mempunyai pengaruh kuat terhadap pemakaian bahasa kedua, sebaliknya bahasa kedua juga mempunyai pengaruh yang besar terhadap pemakaian bahasa pertama. Kebiasaan untuk memakai kedua bahasa lebih secara bergantian disebut kedwibahasaan. Peristiwa semacam ini dapat menimbulkan interferensi.

Interferensi adalah terbawa masuknya unsur bahasa lain ke dalam bahasa yang sedang digunakan, sehingga tampak adanya penyimpangan kaidah dari bahasa yang sedang digunakan itu. Alwasilah (dalam Aslinda dan Leni, 2010:66) mengatakan "interferensi berarti adanya saling pengaruh antarbahasa. Pengaruh itu dalam bentuk pengambilan satu unsur dari satu bahasa dan digunakan dalam hubungannya dengan bahasa lain". Maksudnya, pernyataan tersebut adalah antara penguasaan B1 dan B2 akan saling memengaruhi ketika digunakan dalam situasi tertentu.

Pengaruh tersebut sebenarnya, jika dilihat dari segi kepentingan bahasa Indonesia, pengaruh yang berasal dari bahasa pertama ada yang menguntungkan, tetapi ada juga yang mengacaukan. Interferensi yang mengacaukan ini menimbulkan bentuk-bentuk dan menjadi saingan terhadap bentuk yang sudah lama dan mapan dalam bahasa Indonesia. Sekarang ini, kita tengah menghadapi semua bentuk pengaruh itu (Sumarsono, 2010:235).

Berdasarkan pendapat para pakar bahasa di atas, dapat disimpulkan bahwa interferensi merupakan suatu gejala dari adanya kontak bahasa yang dianggap sebagai penyimpangan dan hanya terjadi pada dwibahasawan, dan tidak akan pernah terjadi pada masyarakat yang monolingual.

Chaer (2012:122) membagi jenis interferensi menjadi dua, yakni "interferensi reseptif dan interferensi produktif". Interferensi reseptif yang dimaksud adalah interferensi yang terjadi dalam proses interpretasi, yakni berupa penggunaan B2 dengan diresapi unsur-unsur B1, sedangkan interferensi produktif adalah interferensi yang terjadi pada proses representasi yang wujudnya berupa penggunaan B1 dengan unsur dan struktur B2.

Weinreich (dalam Aslinda dan Leni, 2010:66--67) melengkapi pendapat di atas dengan mengidentifikasikan empat jenis interferensi, yakni pemindahan unsur dari satu bahasa ke bahasa lain, perubahan fungsi dan kategori unsur karena proses pemindahan, penerapan unsur-unsur yang tidak berlaku pada bahasa kedua ke dalam bahasa pertama, pengabaian struktur bahasa kedua karena tidak terdapat padanannya dalam bahasa pertama.

Interferensi dapat terjadi pada semua tataran bahasa, baik itu fonologi, morfologi, dan sintaksis. Dilihat dari segi kemurnian bahasa, interferensi pada tingkat apa pun merupakan suatu virus yang dapat merusak bahasa. Jadi, interferensi tersebut perlu dihindarkan.

\subsection{Bahasa Melayu dan Bahasa Indonesia}

Bahasa Melayu adalah anggota dari rumpun bahasa Austronesia. Caher (2007:27) menegaskan "perkembangannya, 
bahasa Melayu pada awalnya digunakan oleh penduduk di pesisir timur Pulau Sumatera, wilayah selatan Muangthai, Semenanjung Malaya, Singapura, Brunei dan lainnya". Selain itu, bahasa Melayu juga melahirkan dua buah bahasa resmi kenegaraan yaitu bahasa Malaysia dan bahasa Indonesia. Bahasa Malaysia digunakan sebagai bahasa resmi di Negara Malaysia, sedangkan bahasa Indonesia digunakan sebagai bahasa resmi di Negara Republik Indonesia. Merujuk persamaan asal usul terbentuknya kedua bahasa tersebut, tentu saja antara bahasa Malaysia dengan bahasa Indonesia memiliki kesamaan.

\subsubsection{Bahasa Indonesia}

Bahasa Indonesia terbentuk dari bahasa Melayu dan kosakata bahasa Indonesia pada awalnya adalah kosakata bahasa Melayu. Kontribusi penambahan kosakata bahasa Indonesia, disebabkan pengaruh masyarakat India yang membawa agama Hindu-Budha. Perkembangan agama tersebut, tentu tidak lepas terjadinya kontak bahasa yang menggunakan bahasa Sanskerta. Kontak bahasa inilah yang menyebabkan penambahan kosakata bahasa Indonesia. Indonesia tidak hanya menjalin hubungan dengan India, tetapi juga dengan masyarakat Parsi dan Gujarat yang datang untuk menyebarkan agama Islam melalui hubungan perdagangan dengan Indonesia. Hubungan itu memberikan kontribusi penambahan kosakata bahasa Indonesia yang diakibatkan adanya kontak bahasa asalnya, yaitu bahasa Arab.

Selain perkembangan kosakata bahasa Indonesia akibat hubungan perdagangan di atas, kosakata bahasa Indonesia juga lebih banyak menyerap bahasa Belanda. Pertengahan abad XX, Indonesia dijajah oleh Belanda sangat lama (Chaer, 2007:21). Namun, bahasa Indonesia lahir seutuhnya dan menjadi bahasa resmi negara sejak
Sumpah Pemuda tahun 1928 dan proklamasi kemerdekaan.

Bahasa Indonesia menjadi bahasa resmi negara Indonesia untuk mempersatukan perbedaan masyarakat yang terdiri atas beberapa pulau. Perbedaan yang dimaksud adalah perbedaan bahasa daerah dari setiap pulau di Indonesia akan dipersatukan dalam satu bahasa yakni bahasa Indonesia.

\subsubsection{Bahasa Malaysia}

Bahasa Malaysia adalah bahasa resmi Negara Malaysia yang dijadikan alat komunikasi bagi masyarakat Malaysia. Seperti halnya di Indonesia yang menjadikan bahasa Indonesia sebagai bahasa resmi negara Indonesia dan sebagai alat komunikasi untuk mempersatukan perbedaan aneka bahasa di Indonesia. Namun, sekarang bukan hanya orang asli Malaysia saja yang menggunakan bahasa Malaysia, tetapi juga orang Cina yang menetap dan memiliki saham di Malaysia. Orang Indonesia juga ikut andil berbahasa Malaysia, khususnya bagi mereka yang menjadi TKI di Malaysia.

Fenomena saat ini, terdapat para TKI yang baru pulang dari Malaysia menjadi kurang paham terhadap bahasa negara sendiri. Bahkan jika diajak berbicara menggunakan bahasa Indonesia, mereka cenderung lebih menggunakan bahasa Malaysia. Meskipun, antara bahasa Malaysia dan bahasa Indonesia terbentuk dari bahasa Melayu, kosakata dalam bahasa Malaysia dan Indonesia tidak semuanya memiliki bentuk dan makna yang sama. Ada juga yang bentuknya sama tetapi maknanya berbeda, sehingga membuat petutur Indonesia menjadi salah pengertian.

Perbedaan yang terdapat antara kosakata bahasa Malaysia dan bahasa Indonesia bersumber dari faktor kesejarahan kedua bangsa dan bahasa itu (Chaer, 2007:28). Dalam perkembangannya, bahasa 
Malaysia lebih banyak menyerap bahasa Arab, bahasa Inggris, dan berbagai dialek Melayu yang terdapat di wilayah Malaysia. Berbeda dengan bahasa Indonesia, dalam perkembangannya banyak menyerap kosakata dari bahasa Arab, bahasa Belanda, dan bahasa-bahasa daerah yang terdapat di wilayah Indonesia.

\section{Metode Penelitian}

Penelitian ini tergolong penelitian deskriptif kualitatif. Penelitian deskriptif kualitatif merupakan jenis penelitian yang menekankan pada observasi dan keadaan atau fenomena-fenomena yang terjadi dalam masyarakat secara alamiah. Data yang dikumpulkan berasal dari lingkungan yang nyata dan apa adanya, yaitu tentang penyebab dan bentuk interferensi bahasa. Penelitian ini dilaksanakan pada tiga desa (Desa Sikur, Sikur Barat, dan Semaya) di Kecamatan Sikur. Data berupa data verbal yang didapatkan dari para informan penelitian ini. Teknik pengumpulan data yang digunakan yakni observasi, wawancara dan teknik sadap. Teknik analisis data yang digunakan dalam penelitian ini adalah analisis data kualitatif model Miles dan Huberman yakni data collection, data reduction, data display, dan conclusions (Sugiyono, 2010:92).

\section{Pembahasan}

\subsection{Penyebab Interferensi Bahasa Malaysia}

Dari hasil observasi dan penelitian yang telah dilakukan peneliti, dapat dilihat bahwa penyebab terjadinya interferensi bahasa Melayu Malaysia terhadap bahasa Indonesia pada TKI di Dusun Getap Kecamatan Suralaga ada tiga, sebagai berikut.

\subsubsection{Pergaulan dengan Orang Melayu}

Ketika berada di Malaysia para TKI berinteraksi dengan masyarakat setempat,

$\begin{array}{lllr}\text { sehingga menuntut mereka untuk } & \\ \text { menggunakan bahasa } & \text { Melayu agar } \\ \text { pergaulan dan proses } & \text { komunikasi } & \text { yang }\end{array}$

pergaulan dan proses komunikasi yang terjadi antar mereka bisa berjalan dengan lancar. Menurut pernyataannya, mereka harus menggunakan bahasa Malaysia ketika bergaul dengan orang Melayu dan berkomunikasi dengan majikan. Jika mereka menggunakan bahasa mereka sendiri, orang Melayu dan majikan tidak akan mengerti bahasa yang mereka gunakan. Hal tersebut menuntut para TKI Malaysia untuk menggunakan bahasa Malaysia ketika bergaul dan berinteraksi.

\subsubsection{Kebiasaan Menggunakan Bahasa Malaysia Ketika Berkomunikasi}

Kebiasaan menggunakan bahasa

Malaysia ketika berada di Malaysia membuat para TKI tidak bisa melupakan bahasa tersebut, sehingga setiap berbicara menggunakan bahasa Indonesia, pasti ada serpihan bahasa Malaysia yang masuk ke dalam bahasa Indonesia yang sedang digunakan. Menurut pernyataan informan, menggunakan bahasa Malaysia sudah menjadi suatu kebiasaan untuk berkomunikasi ketika berada di Malaysia, sehingga membuat para TKI sulit untuk melupakan bahasa tersebut.

\subsubsection{Lamanya Menjadi TKI di Malaysia}

Lamanya menjadi TKI di Malaysia membuat para TKI menguasai bahasa Malaysia, meskipun tidak begitu sempurna. Pergaulan dan kebiasaan menggunakan bahasa Malaysia membuat bahasa tersebut tidak mudah untuk dihilangkan dari para TKI. Terlebih bagi mereka yang tidak mendapatkan bahasa Indonesia sebagai B2nya, sehingga tanpa disadari para TKI Malaysia memperoleh bahasa Malaysia sebagai B2-nya. Chaer dan Agustina (2010:86) mengatakan bahwa "seseorang yang terlalu lama tinggal dalam masyarakat tutur B2-nya (terlepas dari masyarakat tutur 
B1-nya), akan mempunyai kesempatan yang lebih luas untuk menggunakan B2-nya daripada B1-nya".

\subsection{Bentuk Interferensi Bahasa Malaysia 4.2.1 Interferensi Fonologi}

Beberapa bentuk interferensi fonologi bahasa Melayu Malaysia terhadap bahasa Indonesia yang dilakukan oleh para TKI Malaysia yang ada Kecamatan Sikur sebagai berikut.

Tabel 1. Bentuk Interferensi Fonologi Bahasa Melayu

\begin{tabular}{|c|c|c|}
\hline BM & & BI \\
\hline$[\mathrm{sAp} \star] \quad /$ sape/ & $\longrightarrow$ & [siapa] \\
\hline$[\mathrm{sAm} \star] \quad$ /same/ & $\longrightarrow$ & [sAma] /sama/ \\
\hline$[\mathrm{Ap} \star] \quad$ /ape/ & $\rightarrow$ & [Apa $]$ \\
\hline [sAy $\star$ ] $]$ /saye/ & $\longrightarrow$ & [sAya] \\
\hline$[$ jug $\star$ ] & $\longrightarrow$ & [juga] \\
\hline$[\mathrm{Iy} \star$ $]$ & $\rightarrow$ & [Iya ] \\
\hline [bias $\star$ ] $]$ /biase/ & $\rightarrow$ & [biasa] /biasa/ \\
\hline$[\mathrm{mAn} \star]]$ /mane/ & $\rightarrow$ & [mAna] /mana/ \\
\hline $\begin{array}{l}{[\mathrm{b} \star \text { rap } \star]} \\
\text { /berape/ }\end{array}$ & & 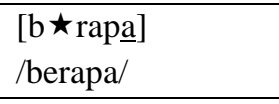 \\
\hline$\left[\mathrm{sAn} \star{ }^{\prime}\right]$ /sane/ & $\rightarrow$ & [sAna] /sana/ \\
\hline [di $\star] \quad / d i e /$ & & [dia] \\
\hline $\begin{array}{l}{[\mathrm{s} \star \mathrm{mu} \star} \\
\text { /semue/ }\end{array}$ & & {$[\mathrm{s} \star$ mua $]$ /semua/ } \\
\hline$[1 \mathrm{Am} \star] \quad /$ lame/ & & [1Ama] /lama/ \\
\hline$[\mathrm{tA} * \star] \quad /$ tanye/ & $\rightarrow$ & [tA $*$ a $] /$ tanya/ \\
\hline $\begin{array}{l}{[\mathrm{k} \star \text { nap } \star]} \\
/ \text { kenape/ }\end{array}$ & & $\begin{array}{l}{[\mathrm{k} \star \text { napa }]} \\
/ \text { kenapa/ }\end{array}$ \\
\hline
\end{tabular}

Berdasarkan hasil penelitian di atas, dapat dikemukakan bahwa perubahan fonem vokal dari bahasa Malaysia ke dalam bahasa Indonesia terdapat pada akhir kata. Perubahannya terjadi menurut pola berikut.

Tabel 2. Perubahan Fonem Vokal

\begin{tabular}{|l|l|c|l|}
\hline BM & & BI & \multicolumn{2}{|c|}{ Keterangan } \\
\hline$[\star]$ & $\longrightarrow$ & {$[a]$} & $\begin{array}{l}\text { Bila terletak pada suku } \\
\text { ultima }\end{array}$ \\
\hline
\end{tabular}

Tabel 3. Perubahan Fonem Konsonan

\begin{tabular}{|l|l|l|}
\hline \multicolumn{1}{|c|}{ BM } & & \multicolumn{1}{c|}{ BI } \\
\hline $\begin{array}{l}\text { [bua@] } \\
\text { /buak/ }\end{array}$ & & [buat] $/$ buat/ \\
\hline $\begin{array}{l}\text { [dui』] } \\
\text { /duik/ }\end{array}$ & $\longrightarrow$ & [duit] /duit/ \\
\hline
\end{tabular}

Dari hasil penelitian yang telah dilakukan dapat dilihat perubahan fonem konsonan bahasa Malaysia ke dalam bahasa Indonesia. Fonem /k/ dalam bahasa Malaysia yang terletak di akhir kata diubah menjadi fonem /t/ dalam bahasa Indonesia. Perubahannya terjadi menurut pola berikut.

Tabel 4. Pola Perubahan Fonem Konsonan

\begin{tabular}{|c|c|c|lc|}
\hline BM & & BI & \multicolumn{2}{|c|}{ Keterangan } \\
\hline$[\approx]$ & $\longrightarrow$ & {$[\mathrm{t}]$} & $\begin{array}{l}\text { Bila terletak pada suku } \\
\text { ultima }\end{array}$ \\
\cline { 1 - 3 }
\end{tabular}

Tabel 5. Pelesapan Fonem Vokal dan Konsonan

\begin{tabular}{|c|c|c|}
\hline $\mathrm{BM}$ & & $\mathrm{BI}$ \\
\hline [lapan] /lapan/ & $\longrightarrow$ & [ $\underline{\mathrm{d}} \star$ lapan] /delapan/ \\
\hline [isap] /isap/ & $\longrightarrow$ & [isap] \\
\hline [Ada $\underset{*}{*}$ /adang/ & $\longrightarrow$ & [ladaæ] /ladang/ \\
\hline [Ⓢpera] /esok/ & & 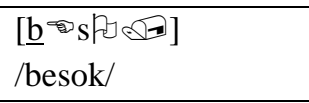 \\
\hline$[\operatorname{ta} \curvearrowleft] \quad / \mathrm{tak} /$ & $\rightarrow$ & [tida $\curvearrowleft]$ \\
\hline 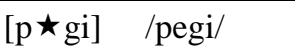 & $\longrightarrow$ & {$[\mathrm{p} \star$ rgi] $\quad /$ pergi/ } \\
\hline [spora艾] /sorang/ & & $\begin{array}{l}\text { [s太何a®] } \\
\text { /seorang/ }\end{array}$ \\
\hline
\end{tabular}

Berdasarkan hasil penelitian yang telah dilakukan dapat dilihat bahwa pelesapan fonem vokal dan konsonan bahasa Malaysia ke dalam bahasa Indonesia terletak pada suku pertama, kedua, dan ketiga kata. Pada suku pertama, kata [lapan] dilesapi fonem konsonan /d/ pada awal kata sehingga menjadi [d $\star$ lapan], kata [isap] dilesapi fonem konsonan $/ \mathrm{h} /$ sehingga menjadi [hisap], kata [ada ${ }_{x}$ ] dilesapi fonem konsonan /l/ sehingga menjadi [lada dilesapi fonem konsonan /b/ sehingga 
menjadi [ $\mathrm{b} s \mathrm{~s} p \in]$. Pada suku kedua, kata [sfora $\left.{ }^{2}\right]$ dilesapi fonem vokal /e/ sehingga menjadi [s $\star$ ora $\otimes$ ]. Pada suku ketiga, kata [p $\star$ gi] dilesapi fonem konsonan /r/ sehingga menjadi [ $p \star$ rgi], dan kata [ta $\approx$ ] dilesapi fonem vokal dan konsonan /i/ dan /d/ sehingga menjadi [tida $₫$ ].

\subsubsection{Interferensi Morfologi Kata Depan $\{\mathbf{k a}\}$}

"Bang, macem mane ketika dicakok ular tu macem mane keadaan ka sane?"

"Kak, seperti apa ketika digigit ular di sana?"

"Aku dengar dekak kawan pun Abang masuk hospital ade pun ka sane"

"Saya dengar dari teman Kakak masuk rumah sakit di sana"

"Abang tak call kita risau lah ka rumah"

"Kakak tidak telpon saya resah di rumah"

"Saya kerja ka sane jual baju"

"Saya kerja di sana jual baju"

"Ka sane oke sangat"

"Di sana baik sekali"

Dari hasil penelitian yang telah dilakukan, dapat dilihat pemakaian kata depan $\{\mathrm{ka}\}$ dalam bahasa Malaysia sejajar makna dan fungsinya sebagai penunjuk tempat dengan kata depan $\{$ di $\}$ dalam bahasa Indonesia.

\subsubsection{Interferensi Sintaksis}

Bentuk interferensi sintaksis bahasa Melayu Malaysia terhadap bahasa Indonesia yang dilakukan oleh para TKI di Dusun Getap dapat dilihat dalam uraian contohcontoh berikut.

Kategori

Besar sangat you punya gaji.

$\mathrm{FV}$

Besar sekali gaji kamu. FN

Kita nak tabuhtai ayam. FN
Kita akan menabur kotoran ayam.

FV

Dari hasil penelitian yang telah dilakukan dapat dilihat terjadi perubahan kategori sintaksis pada setiap frase yang memegang fungsi P. Pada contoh pertama, terdapat perubahan kategori frase verbal (FV) dalam bahasa Malaysia menjadi kategori frase nomina (FN) dalam bahasa Indonesia pada frase yang memegang fungsi P. Sedangkan pada contoh kedua, terjadi perubahan kategori frase nomina (FN) dalam bahasa Malaysia menjadi frase verba (FV) dalam bahasa Indonesia pada frase yang memegang fungsi $P$.

Peran

Besar sangat you punya gaji.

Ket.kuantitas $S_{\text {penanggap }} P_{\text {pemilikan }}$

Gaji kamu besar sekali.

$S_{\text {penanggap }} P_{\text {kuantitas }}$

Buahari punya rokok digigit-gigit.

$\mathrm{S}_{\text {penanggap }} \mathrm{P}_{\text {pemilikan }} \mathrm{O}_{\text {sasaran }}$ Komp pelengkap

Rokoknya Buahari digigit-gigit.

$\mathrm{S}_{\text {penanggap }} \quad \mathrm{P}_{\text {tindakan }}$

Dari hasil penelitian yang telah dilakukan dapat dilihat perubahan peran sintaksis bahasa Malaysia ke dalam bahasa Indonesia. Pada contoh pertama, terjadi perubahan peran pada frase yang memegang fungsi P. Fungsi P pada bahasa Malaysia yang berperan "pemilikan" berubah menjadi peran "kuantitas" pada fungsi $\mathrm{P}$ dalam bahasa Indonesia. Contoh kedua, terjadi perubahan fungsi komplemen dalam bahasa Malaysia yang berperan "pelengkap" menjadi peran "tindakan" pada fungsi $P$ dalam bahasa Indonesia.

Dilihat dari kemurnian bahasa, interferensi dari segi apa pun baik itu interferensi fonologi, morfologi, atau sintaksis merupakan suatu virus yang dapat merusak bahasa. Meskipun interferensi tidak dapat dihilangkan, namun terjadinya interferensi tersebut dapat diatasi. "Semakin tinggi tingkat pendidikan seseorang, semakin maju perekonomiannya, maka 
semakin kurang orang tersebut menghasilkan interferensi" (Aslinda dan Leni, 2010:83). Pendapat tersebut mendeskripsikan bahwa situasi dan kondisilah yang menuntut seseorang untuk berbahasa Indonesia yang baik dan benar.

\section{Penutup}

Penyebab terjadinya interferensi pada TKI Malaysia yaitu, karena pergaulan para TKI dengan orang Melayu, kebiasaan menggunakan bahasa Malaysia ketika berkomunikasi di Malaysia, dan lamanya menjadi TKI di Malaysia.

Bentuk interferensi Bahasa Malaysia terhadap bahasa Indonesia yaitu, interferensi fonologi, morfologi, dan sintaksis. Interferensi fonologi terjadi dalam beberapa bentuk, yakni perubahan fonem vokal, perubahan fonem konsonan, dan pelesapan fonem vokal dan konsonan. Interferensi morfologi hanya terdapat pada kata depan $\{k a\}$. Selain itu, Interferensi sintaksis pada TKI Malaysia terdapat pada kategori dan peran.

\section{Daftar Pustaka}

Aslinda dan Leni Syafyahya. (2010). Pengantar Sosiolinguistik. Bandung: Refika Aditama.

Bloomfield. (1995). Language. (Sutikno, L., Trans.). Jakarta: Gramedia Pustaka Utama.
Chaer, Abdul dan Leoni Agustina. (2010). Sosiolinguistik Perkenalan Awal. Jakarta: Rineka Cipta.

Chaer, Abdul. (2012). Linguistik Umum Edisi Revisi. Jakarta: Rineka Cipta.

\section{(2007). Leksikologi \&} Leksikografi Indonesia. Jakarta: Rineka Cipta.

Dardjowijdjojo, Soenjono. (2008). Psikolinguistik: Pengantar Pemahaman Bahasa Manusia.

Moleong, Lexi. J. (2007). Metodologi Penelitian Kualitatif Edisi Revisi. Bandung: Remaja Rosdakarya.

Ramlan, M. (2009). Morfologi Suatu Tinjauan Deskriptif. Yogyakarta: Karyono.

Sumarsono. (2010). Sosiolinguistik. Yogyakarta. Pustaka Pelajar.

Sugiyono. (2010). Memahami Penelitian Kualitatif. Bandung: Alfabeta.

Thomas, Linda dan Wareing. (2007). Bahasa, Masyarakat dan Kekuasaan. Yogyakarta: Pustaka Pelajar. 